\title{
Hubungan kadar asam urat dengan fungsi kognitif pada lansia
}

\author{
Atikah Ayu Miranda ${ }^{1}$ Alvina $^{2}$
}

\begin{abstract}
ABSTRAK
\section{LATAR BELAKANG}

Gangguan kognitif adalah gangguan dari kemampuan kognitif yang meliputi atensi, kalkulasi, visuospasial, bahasa, memori dan eksekutif yang dapat dijumpai akibat proses degeneratif (penuaan). Asam urat merupakan produk akhir metabolisme purin yang juga disebut sebagai penyumbang antioksidan plasma sehingga dapat mengurangi stres oksidatif dan melindungi dari radikal bebas yang dapat menyebabkan gangguan pada fungsi kognitif. Tujuan penelitian ini adalah untuk mengetahui hubungan antara kadar asam urat darah dengan fungsi kognitif.
\end{abstract}

\section{METODE}

Penelitian ini merupakan studi observasional analitik dengan desain cross sectional yang mengikutsertakan 95 lansia di Posbindu Kelurahan Tomang Jakarta Barat. Kriteria inklusi adalah pria dan wanita usia 60 90 tahun, kesadaran kompos mentis, dan dapat berkomunikasi dengan baik. Kriteria eksklusi adalah terdapat riwayat trauma kepala, stroke, tumor otak, kejang, meningitis serta mengonsumsi obat yang dapat meningkatkan atau menurunkan kadar asam urat darah (allopurinol), probenesid. Penelitian dilakukan pada bulan Agustus - Oktober 2018. Data dikumpulkan menggunakan kuesioner, pengukuran kadar asam urat dilakukan dengan menggunakan alat easy touch blood uric acid test strips, sedangkan pemeriksaan fungsi kognitif dilakukan dengan kuesioner mini mental state examination (MMSE). Analisis data menggunakan uji Chisquare dengan tingkat kemaknaan $\mathrm{p}<0.05$.

\section{HASIL}

Mayoritas responden adalah perempuan dengan rentang usia 60-74 tahun. Terdapat hubungan kadar asam urat dengan fungsi kognitif pada lansia $(\mathrm{p}=0.000)$. Selain itu juga bahwa lansia yang memiliki kadar asam urat yang meningkat memiliki fungsi kognitif yang lebih baik.

\section{KESIMPULAN}

Terdapat hubungan yang bermakna antara kadar asam urat dengan fungsi kognitif pada lansia.

Kata kunci : lansia, antioksidan, kadar asam urat, fungsi kognitif

\author{
${ }^{1}$ Program Studi Kedokteran, \\ Fakultas Kedokteran, \\ Universitas Trisakti \\ ${ }^{2}$ Departemen Patologi Klinik, \\ Fakultas Kedokteran, \\ Universitas Trisakti
}

\section{Korespondensi:}

Alvina

Departemen Patologi Klinik,

Fakultas Kedokteran,

Universitas Trisakti,

Jalan Kyai Tapa No. 260, Grogol,

Jakarta Barat

Email: dr.alvina@trisakti.ac.id;

vina_march_dr@yahoo.com

J Biomedika Kesehat 2019;2(2):65-70

DOI: $10.18051 /$ JBiomedKes.2019.

v2.65-70

pISSN: 2621-539X / eISSN: 2621-5470

Artikel akses terbuka (open access) ini didistribusikan di bawah lisensi Creative Commons Attribution 4.0 International (CC-BY 4.0) 


\section{ABSTRACT}

\section{Correlation between uric acid concentration and cognitive function in the elderly}

\section{BACKGROUND}

Cognitive function disorders are disorders of cognitive abilities that include attention, calculation, visuospatial, language, memory and executives that can be found due to degenerative process (aging). Uric acid is the final product of purine metabolism and also referred as a contributor to plasma antioxidant so that it can reduce oxidative stress and also protect brain from free radicals that can cause cognitive disorders. The aim of the study was to improve cognitive function in the elderly by determining the correlation between blood uric acid levels and cognitive function.

\section{METHODS}

Observational analytic study with a cross-sectional design which included 95 elderly people in Posbindu Kelurahan Tomang, West Jakarta. Inclusion criteria are men and women aged 60-90 years and compost mentis, can communicate well. Exclusion criteria were a history of head trauma, stroke, brain tumor, seizures, meningitis and taking drugs that could increase or decrease blood uric acid levels (allopurinol), probenecid. Research in AugustOctober 2018. Data were collected using respondent questionnaires, measuring uric acid levels using easy touch blood uric acid test strips and examination of cognitive function with the MMSE questionnaire. Data analysis with Chi-square test and the significance level used was 0.05 .

\section{RESULT}

The majority respondents were women aged 60-74 years. The results showed that there was a correlation between uric acid levels and cognitive function in elderly $(\mathrm{p}=0.000)$ and also found that elderly who had elevated uric acids levels had better cognitive function.

\section{CONCLUSION}

There is a significant correlation between uric acid levels and cognitive function in the elderly.

Keywords : elderly, antioxidant, uric acid levels, cognitive function

\section{PENDAHULUAN}

Peningkatan jumlah maupun usia harapan hidup lanjut usia menimbulkan permasalahan dan ragam kebutuhan lanjut usia. Usia yang bertambah membuat fungsi fisiologis mengalami penurunan akibat proses degeneratif (penuaan). ${ }^{(1)}$ Menurut World Health Organization (WHO), batasan lansia dibagi menjadi empat yaitu; usia pertengahan (middle age) antara 45-59 tahun, lanjut usia (elderly) antara 60-74 tahun, lanjut usia tua (old) antara 75-90 tahun, dan usia sangat tua (very old) di atas 90 tahun. ${ }^{(2)}$ Salah satu gangguan yang dijumpai pada proses penuaan adalah gangguan fungsi kognitif (GFK).Gangguan kognitif adalah gangguan dari kemampuan kognitif yang meliputi atensi, kalkulasi, visuospasial, bahasa, memori dan eksekutif. ${ }^{(3)}$ Penelitian sebelumnyamenemukan bahwa penurunan volume substansia grisea dan substansia albaterkait dengan penurunan sistem kognitif dan disebut penuaan kognitif. ${ }^{(4)}$ Faktorfaktor yang dapat memengaruhi gangguan fungsi kognitif antara lain faktor genetik, usia, jenis kelamin, ras, faktor penyakit/kondisi kesehatan seperti hipertensi, diabetes mellitus (DM), kelainan jantung, kelainan fungsi tiroid, kelainan kadar lipid, kolesterol, obesitas, alkohol, merokok dan asam urat. ${ }^{(5)}$
Asam urat adalah senyawa sirkulasi darah terlarut dan konstituen dari sitosol sel yangperannya dalam fisiologi manusia masih kontroversial. ${ }^{(6)}$ Asam urat sering dikaitkan dengan peningkatan risiko pada infark miokard, stroke, dan mortalitas kardiovaskular. Mekanisme yang menyebabkan kejadian tersebut adalah stimulasi yang diinduksi asam urat untuk proliferasi sel otot polos pembuluh darah, sifat inflamasi asam urat terlarut dan efek langsung asam urat pada fungsi endotel dengan merusak produksi nitric oxide. ${ }^{(7)}$ Asam urat juga diketahui berfungsi sebagai antioksidan dan merupakan antioksidan yang paling penting dalam serum dengan kontribusi hingga $60 \%$ dari seluruh aktivitas anti radikal bebas dalam tubuh manusia. Asam urat dapat berinteraksi dengan peroxynitrite, yaitu suatu produk toksik yang terbentuk dari reaksi antara anion superoksida dengan nitric oxide (NO) yang dapat merusak sel serta merupakan 'pemakan' radikal bebas seperti $\mathrm{CO}_{3}$ dan $\mathrm{NO}_{2}$, yang mana merupakan pemecahan dari peroxynitrite. Penurunan konsentrasi asam urat dapat menurunkan kapasitas tubuh untuk mencegah aksi peroxynitrite dan radikal bebas lainnya pada komponen neuronal lainnya. ${ }^{(8)}$

Hasil penelitian terdahulu menyimpulkan bahwa stres oksidatif dan akumulasi radikal bebas 
berperan penting dalam manifestasi neuropatologis dari gangguan kognitif. ${ }^{(3)}$ Salah satu teori yang dapat menyebabkan penuaan adalah teori the free radical theory. ${ }^{(9)}$ Mekanisme pertahanan oleh antioksidan terhadap peroksidasi lipid dapat mencegah kerusakan oksidatif pada otakdengan caramenghambat nitrifikasi, yang dimediasi oleh nitrit, mengikat besi, dan menghambat kerusakan oksidatif. ${ }^{(7,10)}$ Selain itu, asam urat juga memanfaatkan aksi antioksidan gluthathione (GSH) untuk mengurangi radikal bebas dengan cara meningkatkan penyerapan sistein melalui aktivasi transporter Excitatory Amino Acid Transporter-1(EAAT-1). Proses tersebut terjadi di neuron hippocampus, sehingga dapat membantu mencegah terjadinya gangguan pada kognitif. ${ }^{(11)}$

Gangguan fungsi kognitif dapat berupa mudah-lupa (forgetfulness) yaitu bentuk gangguan kognitif yang paling ringan. Forgetfulness dapat berlanjut menjadi gangguan kognitif ringan atau Mild Cognitive Impairment (MCI) sampai ke demensia sebagai bentuk klinis yang paling berat. (12)

Hasil penelitian memperlihatkan bahwa kadar asam urat darah yang rendah dapat meningkatkan resiko terjadinya gangguan fungsi kognitif di masa yang akan datang. ${ }^{(13)}$ Penelitian Li et al pada tahun 2010 mendapatkan hasil yaitu kadar asam urat darah yang lebih tinggi pada pria berhubungan dengan resiko gangguan kognitif yang lebih rendah. ${ }^{(14)} \mathrm{Hal}$ ini menguatkan anggapan bahwa stres oksidatif terlibat dalam patogenesis gangguan kognitif serta menguatkan peran protektif antioksidanasam urat. (7) Penelitian oleh Vannorsdall et al pada tahun 2014 menemukan hasil yaitu kadar asam urat darah yang tinggi dapat meningkatkan risiko terjadinya gangguan fungsi kognitif. ${ }^{(15)}$ Hasil yang sama juga didapatkan pada penelitian Suzuki et al tahun 2016 yaitu peningkatan kadar asam urat darah berhubungan dengan penurunan fungsi kognitif. ${ }^{(16)}$ Oleh karena itu, perlu dilakukan penelitian untuk menentukan hubungan kadar asam urat dan fungsi kognitif tersebut.

\section{METODE}

Penelitian ini merupakan jenis penelitian observasional analitik dengan menggunakan rancangan penelitian cross sectional. Penelitian ini dilakukan di Posbindu Kelurahan Tomang, Jakarta Barat yang dilaksanakan pada bulan Agustus hingga Oktober 2018.

Kriteria inklusi pada penelitian ini adalah lansia pria dan wanita dengan usia 60 - 90 tahun dengan kesadaran kompos mentis serta dapat berkomunikasi dengan baik. Kriteria eksklusi adalah mempunyai riwayat trauma kepala, stroke, tumor otak, kejang, meningitis dan mengkonsumsi obat yang dapat meningkatkan atau menurunkan kadar asam urat darah seperti allopurinol, probenesid. Besar sampel pada penelitian ini adalah 95 lansia. Pemilihan sampel dilakukan dengan menggunakan metode cluster random samplingyang akan dilakukan di 5 Posbindu yang sudah dipilih secara acak dari 8 Posbindu yang ada. Setiap Posbindu terpilih diambil 25 sampel.

Pengukuran kadar asam urat darah menggunakan alat easy touch blood uric acid test strips. Prinsip metode alat ini adalah penggunaan katalis bersama dengan teknologi biosensor untuk mengukur konsentrasi asam urat. Sebelum dilakukan pengukuran kadar asam urat darah, subyek penelitian diminta untuk berpuasa minimal 10-12 jam. Rentang nilai rujukan asam urat untuk pria adalah: $2.5-8 \mathrm{mg} / \mathrm{dL}$, wanita $1.9-7.5 \mathrm{mg} /$ dL. ${ }^{(17)}$ Pemeriksaan fungsi kognitif menggunakan kuesioner MMSE. MMSE memiliki skor maksimal 30 dengan interpretasi normal pada rentang nilai 24-30, probable cognitive impairment (PCI) 1723 serta definite cognitive impairment (DCI) 0-16. ${ }^{(18)}$ Karena pada hasil hanya digunakan kategori normal dan penurunan, maka kategori normal/ baik bila skor $>24$ dan gangguan/penurunan fungsi kognitif bila skor $\leq 24$.

Analisis data menggunakan analisis univariat yang disajikan dalam bentuk porsentase dan analisis bivariat menggunakan uji Chi-square dengan tingkat kemaknaan $\mathrm{p}<0.05$. Penelitian ini sudah mendapatkan persetujuan kaji etik dari FK Trisakti dengan no 46/KER/FK/VII/2018.

\section{HASIL \\ Karakteristik subjek penelitian}

Berdasarkan Tabel 1 diketahui bahwa dari 95 sampel didapatkan bahwa lebih banyak jenis kelamin wanita (68.4\%). Untuk usia didapatkan bahwa kategori usia lanjut usia yaitu 60-74 tahun (78.8\%) lebih banyak. Didapatkan pula bahwa pada wanita lansia lebih banyak yang memiliki kadar asam urat yang meningkat yaitu sebanyak 25 lansia (26.3\%). Pada fungsi kognitif didapatkan 
Tabel 1. Karakteristik subjek penelitian

\begin{tabular}{lcc}
\hline Karakteristik responden & Jumlah & Persentase (\%) \\
\hline Jenis Kelamin & 30 & 31.6 \\
Pria & 65 & 68.4 \\
Wanita & & 78.9 \\
Umur & 75 & 21.1 \\
Lanjut usia (60-74 tahun) & 20 & 40 \\
Lanjut usia tua (75-90 tahun) & & 60 \\
Kadar Asam Urat Darah & 12 & 62 \\
Pria Normal (2.5-8 mg/dL) & 18 & 38 \\
Pria Meningkat (>8 mg/dL) & 40 & \\
Wanita Normal (1.9-7.5 mg/dL) & 25 & 67.4 \\
Wanita Meningkat $(>7.5 \mathrm{mg} \cdot \mathrm{dL})$ & & 32.6 \\
Fungsi Kognitif & 64 & \\
Normal & 31 & \\
Penurunan Fungsi Kognitif & &
\end{tabular}

Keterangan: $\mathrm{mg} / \mathrm{dL}=$ =miligram per desiliter; $\mathrm{mg} . \mathrm{dL}=$ miligram desiliter

bahwa lebih banyak lansia yang memiliki fungsi kognitif yang baik (67.4\%).

Hubungan kadar asam urat dengan fungsi kognitif

Berdasarkan Tabel 2, lansia yang memiliki kadar asam urat meningkat terdapat 42 lansia (97.7\%) memiliki fungsi kognitif yang baik, hal ini lebih besar dibandingkan pada lansia dengan kadar asam urat normal dan memiliki fungsi kognitif baik yaitu terdapat 22 lansia (42.3\%).

Berdasarkan hasil analisis yang dilakukan dengan uji Chi-square diperoleh nilai $\mathrm{p}=0.000$ sehinggadapat disimpulkan terdapat hubungan yang bermakna antara kadar asam urat dengan fungsi kognitif pada lansia.

\section{PEMBAHASAN}

Pada penelitian ini didapatkan bahwa responden wanita lebih banyak daripada pria dikarenakan pada Posbindu tempat pengambilan sampel didapatkan wanita lebih aktif dan lebih sering berpartisipasi dalam kegiatan Posbindu daripada pria.

Untuk kategori umur didapatkan responden dengan rentang umur 60-74 tahun lebih banyak daripada rentang umur 75-90 tahun dikarenakan pada Posbindu didapatkan bahwa tidak banyak terdaftarnya lansia dengan kategori umur 75-90 tahun. Menurut World Health Organization (WHO), batasan lansia dibagi menjadi empat yaitu; usia pertengahan (middle age) antara 45-59 tahun, lanjut usia (elderly) antara 60-74 tahun, lanjut usia tua (old) antara 75-
90 tahun, dan usia sangat tua (very old) di atas 90 tahun. ${ }^{(2)}$

Hasil penelitian ini menunjukkan bahwa pada wanita lansia lebih banyak memiliki kadar asam urat yang tinggi dibandingkan pria hal tersebut dikarenakan saat menopause, tingkat estrogen yang memiliki efek uricosuric pada wanita menurun dan wanita menjadi lebih sering mengalami peningkatan kadar asam urat. ${ }^{(19)}$ Penelitian yang dilakukan oleh Hak dan Choi mendapatkan bahwa kadar asam urat meningkat pada wanita usia 50-59 tahun dan meningkat tertinggi pada usia sekitar 70 tahun. Peningkatan kadar asam urat tersebut berhubungan dengan status menopause. ${ }^{(20)}$

Pada fungsi kognitif didapatkan bahwa lebih banyak lansia yang memiliki fungsi kognitif baik. Terdapat faktor-faktor yang signifikan dalam perubahan kognitif berkaitan dengan usia dari individu ke individu antara lain genetika, penyakit medis, faktor psikologis dan adanya defisit sensorik seperti gangguan penglihatan dan pendengaran serta gaya hidup, studi menunjukkan bahwa mempertahankan hidup aktif dan terlibat dalam aktivitas tertentu selama hidup seseorang dapat membantu mencegah penurunan fungsi kognitif terkait usia. ${ }^{(2)}$ Ada beberapa aktivitas yang berhubungan dengan fungsi kognitif untuk lansia seperti aktivitas yang menggunakan intelektualitas (permainan puzzle, membaca, bermain kartu, bermain instrumen musik, menggunakan komputer), aktivitas fisik (berolahraga, berkebun atau berdansa), aktivitas sosial (bersosialisasi dengan keluarga dan teman, 
Tabel 2. Hubungan kadar asam urat dengan fungsi kognitif responden

\begin{tabular}{|c|c|c|c|c|c|}
\hline \multirow{3}{*}{ Kadar asam urat } & \multicolumn{4}{|c|}{ Fungsi kognitif } & \multirow{3}{*}{$\mathbf{p}$} \\
\hline & \multicolumn{2}{|c|}{ Baik } & \multicolumn{2}{|c|}{ Penurunan } & \\
\hline & $\mathbf{n}$ & $\%$ & $\mathbf{n}$ & $\%$ & \\
\hline Normal & 22 & 42.3 & 30 & 57.7 & \multirow{2}{*}{$0.000=$} \\
\hline Meningkat & 42 & 97.7 & 1 & 2.3 & \\
\hline
\end{tabular}

$\ddagger$ : Uji Chi-square dengan $\mathrm{p}<0.05$ hubungan bermakna

berwisata, melakukan kegiatan kebudayaan). ${ }^{(21)}$ Aktivitas fisik rutin dan tinggi berhubungan dengan fungsi kognitif yang tinggi. Beraktivitas fisik dengan berolahraga seminggu tiga kali untuk lansia akan meningkatkan kebugaran tubuh dan menstimulasi faktor tropic serta neuronal growth yang akan menghambat penurunan fungsi kognitif. ${ }^{(18)}$

Dari hasil analisis dengan uji Chi square didapatkan $\mathrm{p}=0.000(\mathrm{p}<0.05)$ sehingga terdapat hubungan yang bermakna antara kadar asam urat dengan fungsi kognitif. Berdasarkan frekuensi menunjukkan bahwa frekuensi terbesar baik pada pria maupun wanita lansia adalah kadar asam urat yang meningkat dan fungsi kognitif yang baik.

Hal ini sejalan dengan penelitian yang dilakukan oleh Wu et al di China dimana didapatkan kadar asam urat darah yang lebih tinggi secara independen berhubungan dengan fungsi kognitif global yang lebih baik. Asam urat memiliki sifat antioksidan yang kuat sehingga dapat mengurangi stres oksidatif dan melindungi otak dari efek merusak radikal bebas. ${ }^{(22)}$ Asam urat memanfaatkan aksi antioksidan GSH untuk mengurangi radikal bebas dengan cara meningkatkan penyerapan sistein melalui aktivasi transporter EAAT-1 di neuron hippocampus, sehingga dapat membantu mencegah terjadinya gangguan pada kognitif. ${ }^{(8)}$ Asam urat di dalam plasma memiliki aktivitas sebagai 'pemakan' radikal bebas yang kuat. (23) Asam urat mampu menonaktifkan berbagai oksigen reaktif dan juga berbagai jenis nitrogen termasuk radikal bebas peroksil dan hidroksil, peroksinitrit dan oksida nitrat. ${ }^{(10)}$ Untuk dapat 'memakan' peroksinitrit, asam urat membutuhkan adanya asam askorbat dan thiol. Baik antioksidan asam askorbat maupun thiol tidak ada yang mampu mencegah reaksi peroksinitrit dengan tetrahydrobiopterin yang dapat menyebabkan terlepasnya tetrahydrobiopterin dari nitric oxide synthase. Hal inilah yang menunjukkan bahwa asam urat memiliki peran yang penting sebagai 'pemakan' peroksinitrit. ${ }^{(24)}$

Terdapat keterbatasan pada penelitian ini yaitu konsumsi purin, riwayat penyakit kronik (penyakit ginjal, hipertensi, diabetes) dan juga gaya hidup (merokok dan alkohol) tidak diteliti dikarenakan keterbatasan alat dan waktu serta tidak diperiksa tekanan darah dan kadar gula darah (hanya melalui kuesioner).

\section{KESIMPULAN}

Terdapat hubungan yang bermakna antara kadar asam urat dengan fungsi kognitif pada lansia.Walaupun asam urat memiliki efek protektif terhadap fungsi kognitif, tetapi peningkatan kadar asam urat yang berlebih dapat menjadi faktor resiko terjadinya penyakit kardiovaskular. Oleh karena itu, disarankan perlu dilakukan pemeriksaan kadar asam urat darah secara berkala sebagai upaya pencegahan dan untuk penelitian selanjutnya disarankan untuk meneliti hubungan asam urat dengan fungsi kognitif menggunakan desain kohort prospektif sehingga dapat menjelaskan hubungan sebab akibat secara pasti.

\section{UCAPAN TERIMA KASIH}

Terima kasih kepada Team Posbindu Kelurahan Tomang, Jakarta Barat yang telah memberikan izin pengambilan data penelitian.

\section{KONFLIK KEPENTINGAN}

Tidak ada konflik kepentingan antara penulis.

\section{KONTRIBUTOR}

Atikah Ayu Miranda pengumpulan data, penanggung jawab pengumpulan data di lapangan, persiapan makalah. Alvina merevisi makalah akhir untuk publikasi. Atikah Ayu Miranda dan Alvina menyusun konsep, merancang penelitian, analisa data dan interpretasi data. 


\section{DAFTAR REFERENSI}

1. Pali C. Gambaran Kebahagiaan pada Lansia yang memilih tinggal di Panti Werdha. Jurnal e-Biomedik2016;4(1):1-6.

2. WHO. What is age. 2013. Available at: http:// who.int/healthinfo/survey/ageingdefnolder/en/. Accessed May 23, 2018

3. Kementerian Kesehatan Republik Indonesia. Pedoman Rehabilitasi Kognitif. Jakarta: Kemenkes;2010.

4. Manan HA, Yusoff AN, Zamratol S, et al. The effect of ageing on brain effectiveconnectivity during working memory processing from the perspective of dynamic causal modelling. Sains Malays 2015;44(9):1339-50.

5. Patterson C, Feightner JW, Garcia A, et al. Diagnosis and treatment of dementia: 1. Risk assessment and primary prevention of Alzheimer disease. CMAJ 2008;178(5):548-56. DOI: 10.1503/cmaj.070796

6. Ruggiero C, Cherubini A, Lauretani F, et al. Uric Acid and Dementia in Community-Dwelling Older Persons. Dement Geriatr Cogn Disord 2009;27:382-9. DOI: 10.1159/000210040

7. Euser SM, Hofman A, Westendorp RGJ, et al. Serum uric acid and cognitive function and dementia. Brain 2009;132:377-82. DOI: 10.1093/ brain/awn 316

8. Lario BA, Vicente JM. Urid acid and evolution. Rheumatology 2010;49:2010-5. DOI: 10.1093/ rheumatology/keq204

9. Pangkahila JA. Pengaturan pola hidup dan aktivitas fisik meningkatkan umur harapan hidup. Sport and Fitness Journal 2014;1(1):1-7.

10. Xue LL, Liu YB, Xue HP, et al. Low uric acid is a risk factor in mild cognitiveimpairment. Neuropsychiatr Dis Treat 2017;13:2363-7.

11. Giorgi AD, Fabbian F, Pala M, et al. Uric acid: friend or foe? uric acid and cognitive function "gout kills more wise men than simple". Eur Rev Med Pharmacol Sci 2015;19:640-6.

12. Wreksoatmodjo, BR. Beberapa kondisi fisik dan penyakit yang merupakan faktor risiko gangguan fungsi kognitif. CDK 2014;41:25-32.

13. Aramburu IG, Juan PS, Sierra M, et al. Serum uric acid and risk of dementia in Parkinson's disease. Parkinsonism Relat Disord 2014;20(6):637-9. DOI: 10.1016/j.parkreldis.2014.02.023

14. Li J, Dong BR, Lin P, et al. Association of cognitive function with serum uric acid level among Chinese nonagenarians and centeranians. Exp Gerontol2010;45:331-5. DOI: 10.1016/j. exger.2010.01.005

15. Vannorsdall TD, Kueider AM, Carlson MC, et al. Higher baseline serum uric acid is associated with poorer cognition but not rates of cognitive decline in women. Exp Gerontol 2014;60:136-9. DOI: 10.1016/j.exger.2014.10.013

16. Suzuki K, Koide D, Fuji K, et al. Elevated serum uric acid levels are related to cognitive deterioration in elderly japanese population. Dement Geriatr Cogn Disord Extra 2016;6:580-8. DOI: $10.1159 / 000454660$

17. Devkota BP. Uric acid. Medscape 2014. Available at: https://emedicine.medscape.com/ article/2088516-overview\#showall. Accessed May 23,2018.

18. Muzamil MS, Afriwardi, Martini RD. Hubungan antara tingkat aktivitas fisik dengan fungsi kognitif pada usila di Kelurahan Jati Kecamatan Padang
Timur. JKA 2014;3(2):202-5.

19. Kumar S, Gupta R, Suppiah R. Gout in women: differences in risk factors in young and older women. NZMedJ 2012;125(1363):39-45

20. Hak AE, Choi HK. Menopause, postmenopausal hormone use and serum uric acid levels in US women, The third national health and nutrition examination survey. Arthritis Res Ther 2008;10(R116):1-7. DOI:10.1186/ar2519

21. Harada CN, Love MCN, Triebel K. Normal cognitive aging. Clin Geriatr Med 2013;29(4):73752. DOI: 10.1016/j.cger.2013.07.002

22. Wu Y, Zhang D, Pang Z, et al. Association of serum uric acid level with muscle strength and cognitive function among Chinese aged 50-74 years. Geriatr Gerontol Int 2013;13:672-7. DOI: 10.1111/j.14470594.2012.00962x

23. Amic A, Markovic Z, Dimitric JM, et al. The $2 \mathrm{H}^{+} / 2 \mathrm{e}^{-}$free radical scavenging mechanisms of uric acid: thermodynamics of $\mathrm{N}-\mathrm{H}$ bond cleavage. Comput Theor Chem 2016;1077:2-10. DOI: 10.1016/j.comptc.2015.09.003

24. Nimse SB, Pal D. Free radicals, natural antioxidants, and their reaction mechanisms. RSC Adv 2015;5;27986-8006. DOI: 10.1039/c4ra $13315 \mathrm{c}$ 